\title{
Studi Case Report: Kejadian Luar Biasa Keracunan Makanan di Desa Parikesit Kecamatan Kejajar Kabupaten Wonosobo
}

\author{
Case Report Study: Food Poisoning Outbreak in Parikesit Village, \\ Kejajar District, Wonosobo Regency
}

\author{
Anita Nugrahaeni ${ }^{1}$, Julia Pertiwi ${ }^{2}$ \\ ${ }^{1}$ Bidang Pencegahan dan Pengendalian Penyakit, Dinas Kesehatan Kabupaten Wonosobo \\ ${ }^{2}$ Prodi D3 Rekam Medis \& Informasi Kesehatan, Universitas Veteran Bangun Nusantara Sukoharjo \\ Email : nitaozora@gmail.com
}

\begin{abstract}
There has been an increase in cases of suspected food poisoning in Parikesit Village, Kejajar District, Wonosobo Regency, Central Java Province. This case report will describe the events and factors that caused of food poisoning outbreak. The epidemiological investigation was carried out by the Health Office Team by investigating all participant who consuming food at Kartini's Day. They are grouped into cases and controls, in cohorts followed by the development of symptoms. The collected data is then analyzed using bivariate and multivariate statistics to determine the factors that cause poisoning. The results showed that residents who consumed fried chili sauce of chicken liver ( $\mathrm{p}<0.001$ ) had a risk of poisoning 14.58 times higher. In addition, consuming "gudeg" ( $p=0.021$ ) increases the risk of poisoning 2.03 times. The most dominant factor was consumed fried chili sauce of chicken liver $(p<0.001)$ and was supported by laboratory results that showed the presence of Enterobacter aerogenes. The steps to overcome and prevent outbreaks have been done well.
\end{abstract}

Keywords: food poisoning, outbreak, epidemiological investigation

\begin{abstract}
ABSTRAK
Telah terjadi peningkatan kasus yang diduga keracunan makanan di Desa Parikesit, Kecamatan Kejajar, Kabupaten Wonosobo, Provinsi Jawa Tengah. Laporan kasus ini akan menggambarkan kejadian dan faktor yang mempengaruhi kejadian keracunan makanan. Penyelidikan epidemiologi dilakukan oleh Tim Penanggulangan KLB Dinas Kesehatan dengan menginvestigasi seluruh warga yang hadir dan mengkonsumsi makanan di acara Kartini's Day. Warga kemudian dikelompokkan menjadi kasus dan control, secara kohort diikuti perkembangan gejala. Data yang telah terkumpul kemudian dianalisis dengan statistic bivariat dan multivariat untuk menentukan faktor penyebab keracunan. Hasil menunjukkan bahwa warga yang mengkonsumsi sambal goreng ati $(\mathrm{p}<0,001)$ berisiko keracunan 14,58 kali lebih tinggi. Selain itu, mengkonsumsi gudeg $(p=0,021)$ meningkatkan risiko keracunan 2,03 kali. Adapun faktor yang paling dominan adalah sambal goreng ati $(\mathrm{p}<0,001)$ dan ditunjang dengan hasil laboratorium yang menunjukkan terdapat bakteri Enterobacter aerogenes. Langkah penanggulangan dan pencegahan KLB telah dilakukan dengan baik.
\end{abstract}

Kata kunci: Keracunan makanan, KLB, penyelidikan epidemiologi 


\section{PENDAHULUAN}

Keracunan makanan terjadi ketika bakteri atau patogen jenis tertentu yang membawa penyakit mengontaminasi makanan, dapat menyebabkan penyakit yang sering disebut dengan" keracunan makanan". Penyebab keracunan makanan bisa disebabkan agen pathogen yang berupa bakteri, jamur, bahan kimia dan logam berat lainnya. Bakteri yang kerap dikaitkan dengan kejadian keracunan makanan meliputi: Salmonella, Campylobacter, Listeria, Clostridium butolinum, dan Escherichia coli. (Centers for Diseases Control and Preventions, 2020) Kontaminasi bakteri ini dapat terjadi dalam penyediaan bahan mentah dan selama proses pengolahan, penyajian dan pengiriman, penyajian dan makanan yang kemungkinan terkontaminasi bakteri dan zat kimia. Gejala klinis yang kerap dialami oleh penderita dapat berupa mual, demam, sakit kepala, muntah, dehidrasi, sakit perut, lemas atau diare. Selain itu, tidak sedikit kasus keracunan makanan yang berujung pada kematian.(U.S. Food \& Drugs Administration, 2020)

Dalam Permenkes Nomor 949/Menkes/SK/VIII/2004 Kementerian Kesehatan Republik Indonesia mengkategorikan kejadian keracunan makanan sebagai Kejadian Luar Biasa (KLB). Kejadian KLB dapat mengakibatkan terjadinya peningkatan kesakitan dan kematian yang besar, berdampak pada pariwisata, ekonomi dan sosial, sehingga membutuhkan perhatian dan penanganan yang serius oleh pihak terkait. (Kemenkes RI, 2004) Kejadian KLB perlu dideteksi secara dini dan diikuti tindakan yang cepat dan tepat, perlu diidentifikasi adanya ancaman KLB beserta kondisi rentan yang memperbesar risiko terjadinya KLB agar dapat dilakukan peningkatan kewaspadaan dan kesiapsiagaan menghadapi kemungkinan KLB. Kewaspadaan ini dapat diakselerasikan dengan kegiatan surveilans. (Pertiwi et al., 2019)

Menurut data WHO terdapat sekitar dua juta orang di dunia meninggal akibat keracunan makanan tiap tahunnya. Data di Indonesia tahun 2017 menunjukkan provinsi dengan KLB keracunan pangan tertinggi pada tahun 2017 adalah Jawa Barat (25 kejadian), Jawa Tengah (17 kejadian), Jawa Timur (14 kejadian), Bali (13 kejadian), dan Nusa Tenggara Barat (12 kejadian). Secara keseluruhan kejadian keracunan makanan yang dilaporkan sepanjang tahun 2017 mengakibatkan kesakitan pada 893 orang dan kematian pada 8 orang. (Rokhmayati and Heryantoro, 2017)

Pada bulan Maret 2019, telah terjadi peningkatan kasus yang diduga keracunan makanan di Desa Parikesit, Kecamatan Kejajar, Kabupaten Wonosobo, Provinsi Jawa Tengah. Laporan kasus berikut ini akan menggambarkan kejadian keracunan makanan dan faktor yang mempengaruhi kejadian keracunan makanan pada desa tersebut. Pada Senin, 25 Maret 2019 pukul 09.00 WIB, Perangkat Desa Parikesit melaporkan kepada petugas Puskesmas setempat bahwa sejak hari Minggu malam, 24 Maret 2019 tercatat 21 orang warga mengalami sakit dengan gejala mual, panas, pusing, sakit perut dan diare. Peristiwa tersebut telah terjadi setelah warga mengkonsumsi makanan katering dalam acara Kartini's Day tanggal 24 Maret 2019 pukul 10.00 WIB di Balai Desa Parikesit. Keluhan mulai dirasakan 3 jam setelah warga mengkonsumsi makanan tersebut. Tamu yang di undang dalam acara tersebut sejumlah 250 orang meliputi Perangkat Desa, BPD, LPMD, KPMD, PKK, Ketua RW, Ketua RT, Tokoh Pemuda, Dewan Juri, Tutor Senam, dan Perwakilan RT. Jumlah tamu undangan yang hadir sejumlah 185 orang. Sejumlah tamu undangan membawa pulang makanan katering mereka dan mengkonsumsinya bersama anggota keluarga lain. Petugas Puskesmas kemudian melaporkan kepada Tim Penanggulangan KLB Dinas Kesehatan. Selanjutnya, tim tersebut langsung melakukan pelacakan kasus dan penyelidikan untuk memastikan adanya peningkatan kasus dan KLB. Definisi kasus dari KLB ini adalah adalah orang yang mengalami salah satu atau lebih gejala mual, mutah, diare, kejang perut, pusing, demam, menggigil, sakit perut, nyeri pinggang dan badan lemas setelah mengkonsumsi makanan katering dalam acara Kartini's Day pada tanggal 24 
Maret 2019 di Desa Parikesit. Sedangkan untuk kelompok kontrol adalah orang yang mengkonsumsi makanan katering dalam acara Kartini's Daya pada tanggal 24 Maret 2019 namun tidak mengalami gejala mual, mutah, diare, kejang perut, pusing, demam, menggigil, sakit perut, nyeri pinggang dan badan lemas.

\section{METODE}

Penyelidikan dilakukan dengan menggunakan rancangan cohort study. Teknik pengumpulan data dengan wawancara menggunakan kuesioner. Data yang berhasil dikumpulkan kemudian dikaji secara deskriptif berdasarkan epidemiologi menurut orang, tempat, dan waktu. Analisis data bivariat untuk menilai kemaknaan hubungan antar variabel dengan menggunakan uji statistic chi-square, yang dilanjutkan dengan analisis multivariat dengan regresi logistic untuk mengetahui faktor dominan yang menyebabkan keracunan makanan.

HASIL DAN PEMBAHASANSesuai dengan Buku Pedoman Penyelidikan dan Penanggulangan Kejadian Luar Biasa Penyakit Menular dan Keracunan Pangan (Pedoman E[idemiologi Penyakit) Kementerian Kesehatan Republik Indonesia Tahun 2011, penyelidikan KLB keracunan makanan dilakukan dengan beberapa langkah. Langkahlangkah yang dimaksud meliputi: (1) distrbusi kasus berdasarkan gejala dan jenis makanan; (2) pemastian diagnosis; (3) kurva epidemiologi; (4) gambaran epidemiologi; (5) identifikasi faktor; (6) hasil laboratorium; dan (7) penanggulangan dan pencegahan. (Ditjen P2PL, 2011)

\section{Hasil Pelacakan}

Hasil penyelidikan epidemiologi pada tanggal 25 - 27 Maret 2019 menunjukkan adanya kasus sebanyak 225 orang dari 276 dengan gejala mual, muntah, diare, kejang perut, pusing, demam, menggigil, sakit perut, nyeri pinggang, badan pegel, mules, lemas, dan disentri. Berdasarkan Gambar 1, diketahui bahwa gejala yang paling banyak dialami adalah diare (211 orang), mules (204 orang) dan sakit perut (185 orang).

Berdasarkan gejala-gejala klinis tersebut maka diduga telah terjadi KLB keracunan makanan di dengan sumber keracunan diduga berasal dari makanan katering yang diterima warga pada hari Minggu, 24 Maret 2019. Makanan tersebut dipesan dari salah satu Katering di Desa Kejajar. Jenis makanan yang dikonsumsi oleh warga tersaji pada Gambar 2 dengan jenis makanan yang paling banyak dikonsumsi adalah nasi (218 orang; 96,8\%), diikuti telur puyuh sambal goreng ati (184 orang; 94,6\%) dan ayam (184 orang; 81,7\%).

\section{Pemastian Diagnosis}

Pemastian diagnosa dilakukan terhadap gejala klinis yang ada. Sampel makanan berhasil diamankan dan dikirim ke Laboratorium Kesehatan Daerah Kabupaten Wonosobo.

\section{Kurva Epidemiologi}

Lama paparan menggambarkan perjalanan alamiah suatu penyakit, mulai dari seseorang yang rentan terhadap penyakit dan diserang oleh agen patogenik sampai menimbulkan gejala penyakit (riwayat alamiah yang berbeda-beda). Masa inkubasi keracunan makanan yang terjadi di Desa Parikesit rata-rata 12 jam. Warga mulai mengkonsumsi makanan pada Minggu, 24 Maret 2019 pukul 12.00 WIB. Gejala keracunan mulai dirasakan pada tanggal 24 Maret 2019 pukul 15.00 WIB, dengan kasus terbanyak pada tanggal 25 Maret 2019 pukul 02.00 WIB.

Kurva epidemic tipe common source pada Gambar 3 menunjukkan KLB terjadi pada satu kelompok orang, berasal dari satu sumber. Gambaran tentang kenaikan dan 
penurunan kasus dalam kurva epidemik diatas terjadi akibat adanya perbedaan waktu paparan. Dilihat dari masa inkubasi, masa inkubasi terpendek yaitu 2 jam dan masa inkubasi terpanjang yaitu 20 jam (Gambar 3).

\section{Gambaran Epidemiologi}

Penderita keracunan makanan adalah warga yang mengkonsumsi makanan katering dalam acara Kartini's Day di Desa Parikesit pada tanggal 24 Maret 2019. Gambar 4 memperlihatkan bahwa penderita terbanyak adalah kelompok usia 16-40 tahun (63\%), diikuti penderita kelompok usia 41-60 tahun (23\%) dan penderita kelompok usia 6-15 (8\%). Selanjutnya, Gambar 5 memperlihatkan bahwa proporsi penderita lebih banyak pada perempuan yaitu 160 orang (71\%), sedangkan pada laki-laki sejumlah 65 orang (29\%).

Penderita keracunan makanan tersebar di 12 RT dengan distribusi yang tersaji pada Gambar 6. Penderita terbanyak berada di wilayah RT 1 RW 1 (29 orang) dan dari warga luar wilayah Desa Parikesit yang juga mengkonsumsi makanan katering dalam acara Kartini's Day ada 2 orang. Berdasarkan Gambar 7 diketahui bahwa semua warga mengkonsumsi makanan katering dalam acara Kartini's Day pada tanggal 24 Maret 2019. Warga mulai mengkonsumsi makanan tersebut pada pukul 12:00 WIB yaitu sebanyak 3 orang, dan sebagian besar mereka mengkonsumsi makanan tersebut pada pukul 13:30 yaitu sebanyak 115 orang.

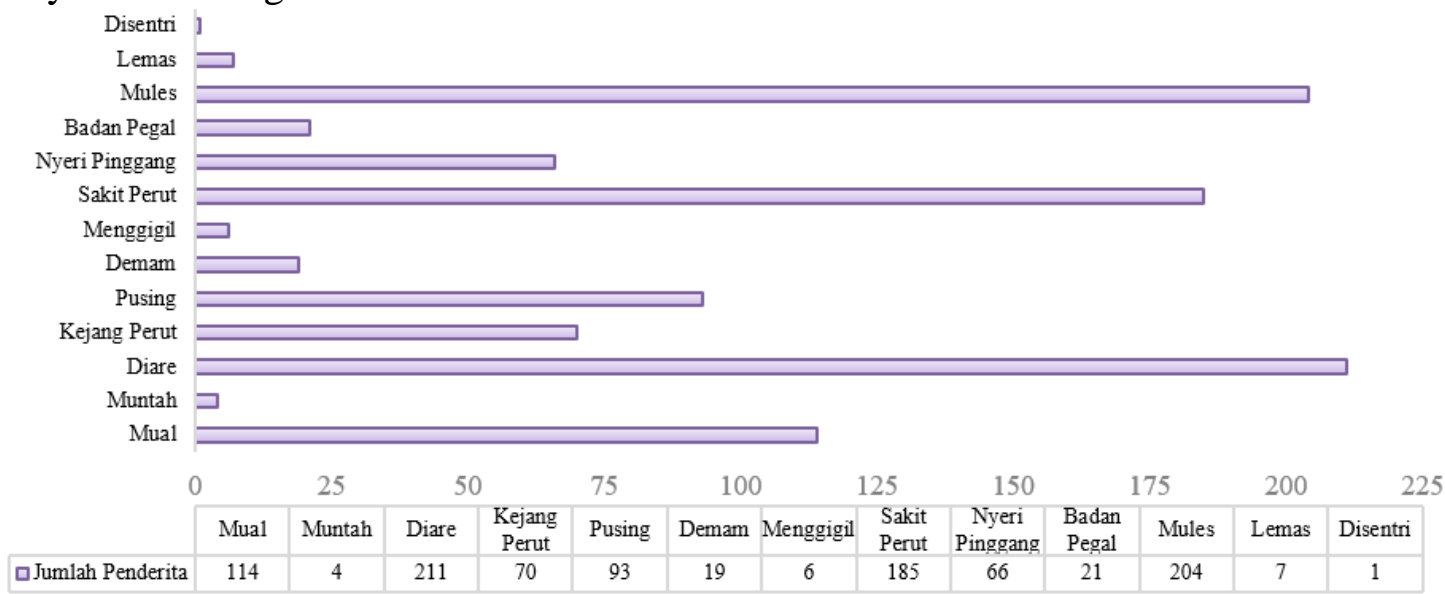

Catatan: 1 kasus mengalami lebih dari 1 gejala

Gambar 1. Distribusi Frekuensi Penderita Keracunan Makanan Berdasarkan Gejala

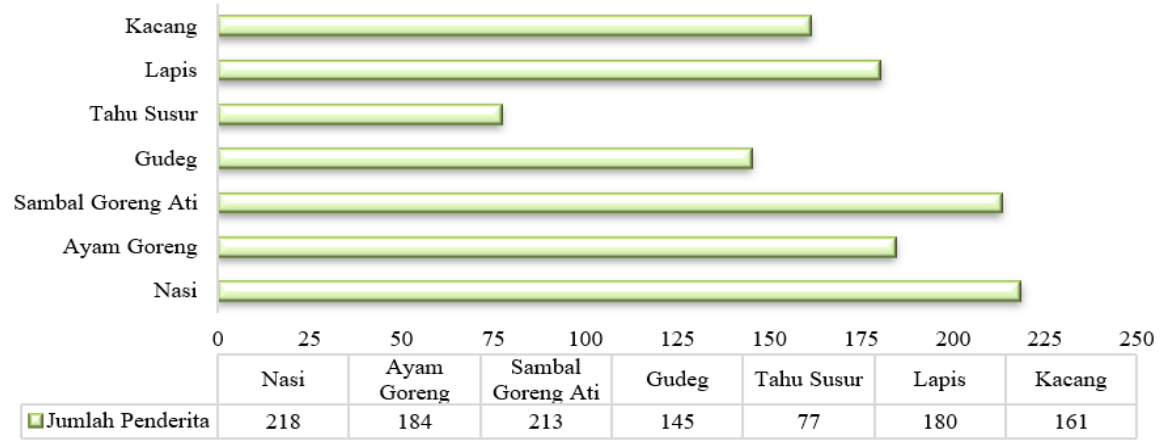

Catatan: 1 kasus mengkonsumsi lebih dari 1 jenis makanan

Gambar 2. Distribusi Frekuensi Penderita Keracunan Makanan

Berdasarkan Jenis Makanan yang Dikonsumsi 


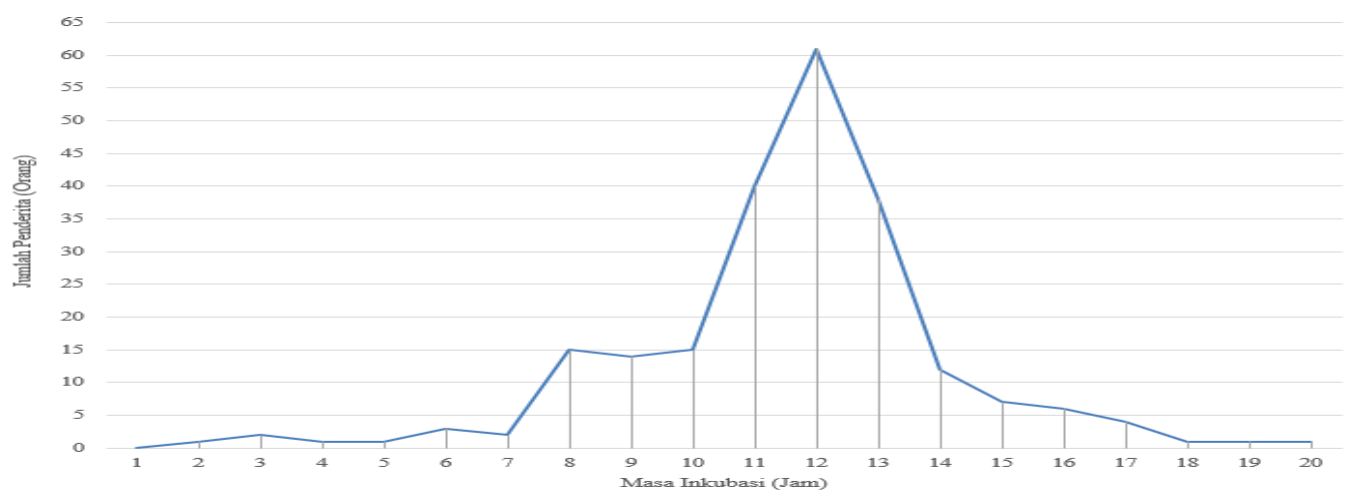

Gambar 3. Kurva epidemiologi KLB keracunan makanan

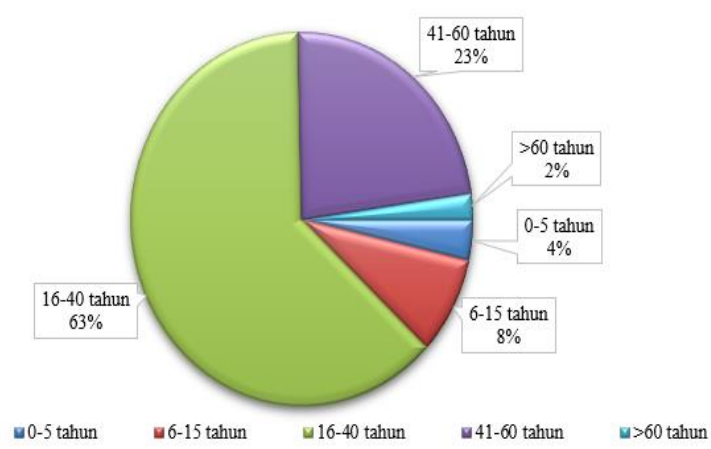

Gambar 4. Distribusi Frekuensi Penderita KLB Keracunan Makanan Berdasarkan Umur

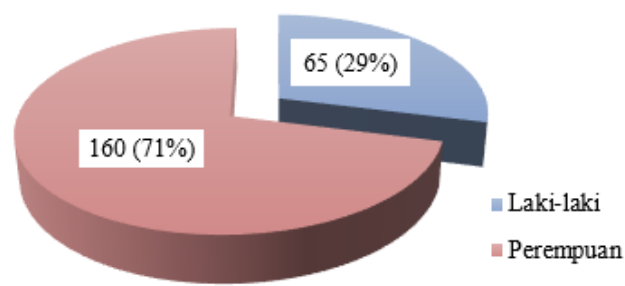

Gambar 5. Distribusi Frekuensi Penderita KLB Keracunan Makanan Berdasarkan Jenis Kelamin

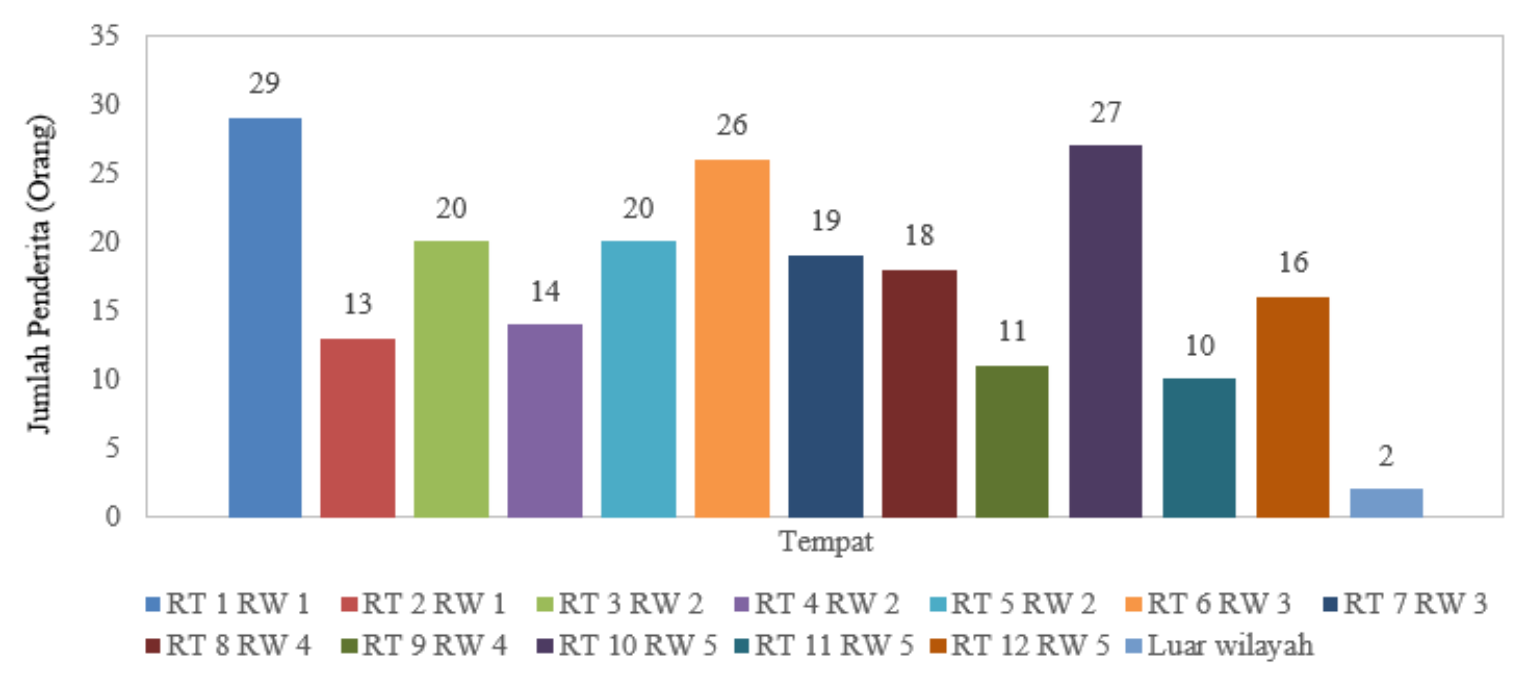

Gambar 6. Distribusi Frekuensi Penderitas KLB Keracunan Makanan Desa Parikesit Tanggal 24-25 Maret 2019 Berdasarkan Tempat 


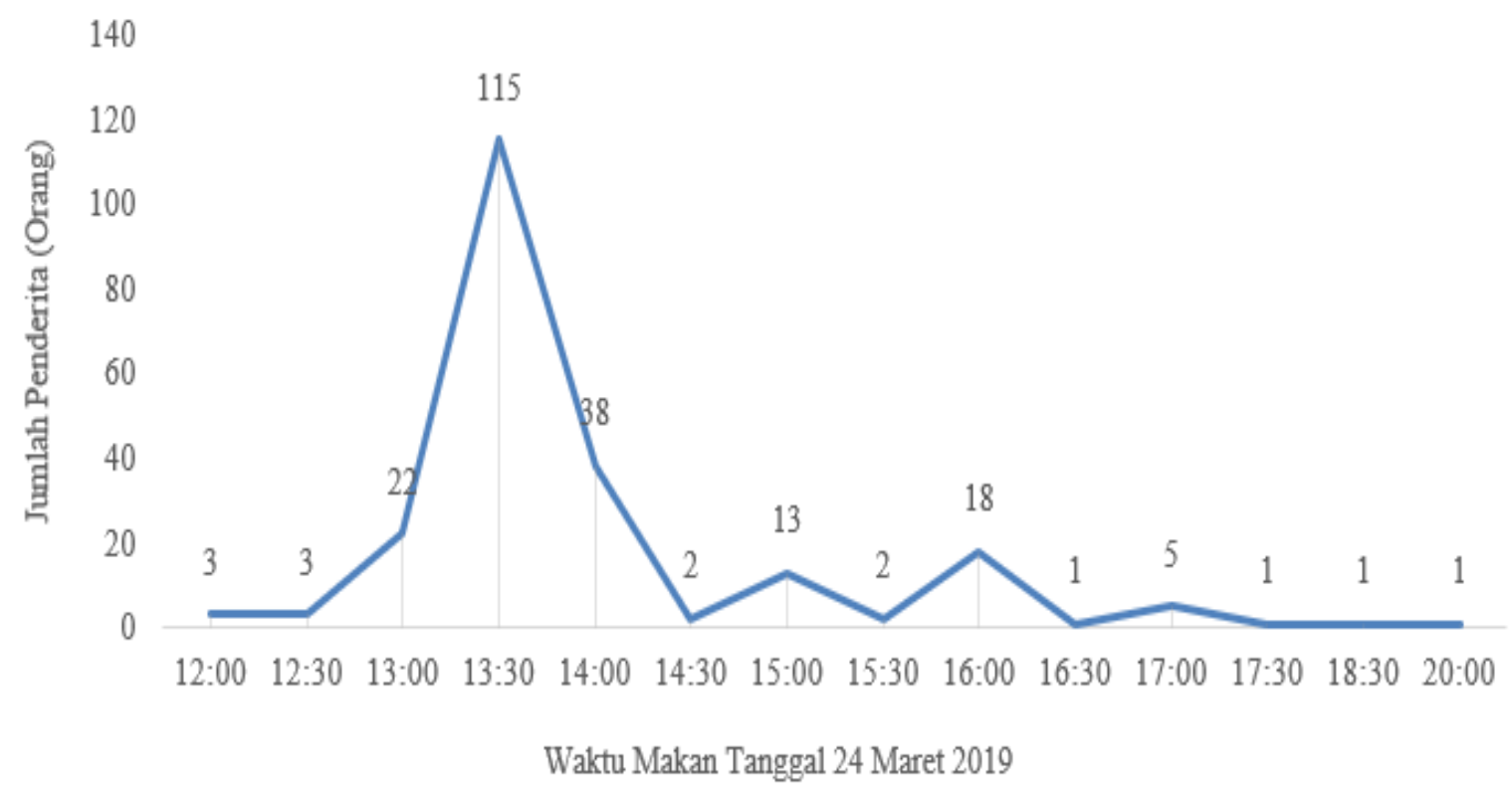

Gambar 7. Distribusi Frekuensi Penderita KLB Keracunan Makanan Desa Parikesit Tanggal 24-25 Maret 2019 Berdasarkan Waktu Mengkonsumsi Makanan

\section{Identifikasi Faktor Risiko}

Penulusuran faktor risiko pada berbagai jenis makanan yang diduga berhubungan terhadap terjadinya KLB keracunan makanan dengan menggunakan analisis bivariat. Uji statistik yang digunakan adalah chi-square dengan melihat nilai $p$. Analisis dilanjutkan dengan analisis multivariat menggunakan logistic regression dengan syarat bila hasil uji bivariat mempunyai nilai $\mathrm{p}<0,25$ maka variabel tersebut dapat masuk model multivariat.

Tabel 1. menunjukkan hasil analisis bivariat hubungan beberapa jenis makanan dengan KLB keracunan makanan Desa Parikesit. Berdasarkan tabel diketahui bahwa mengkonsumsi sambal goreng ati berhubungan dengan kejadian KLB keracunan makanan $(\mathrm{p}<0,001)$ dimana orang yang mengkonsumsi sambal goreng ati berisiko untuk mengalami keracunan 14,58 kali lebih besar dibandingkan orang yang tidak. Selain itu, mengkonsumsi gudeg juga berhubungan dengan kejadian KLB keracunan makanan $(\mathrm{p}=0,021)$ dengan risiko mengalami keracunan 2,03 kali lebih besar dibandingkan dengan mereka yang tidak mengkonsumsi gudeg dalam acara Kartini's Day.

Berdasarkan tabel 2 diketahui bahwa setelah mengontrol variabel lain, mengkonsumsi sambal goreng ati merupakan faktor yang paling dominan $(p<0,001)$. 
Tabel 1. Hasil Uji Bivariat Jenis Makanan dengan KLB Keracunan Makanan

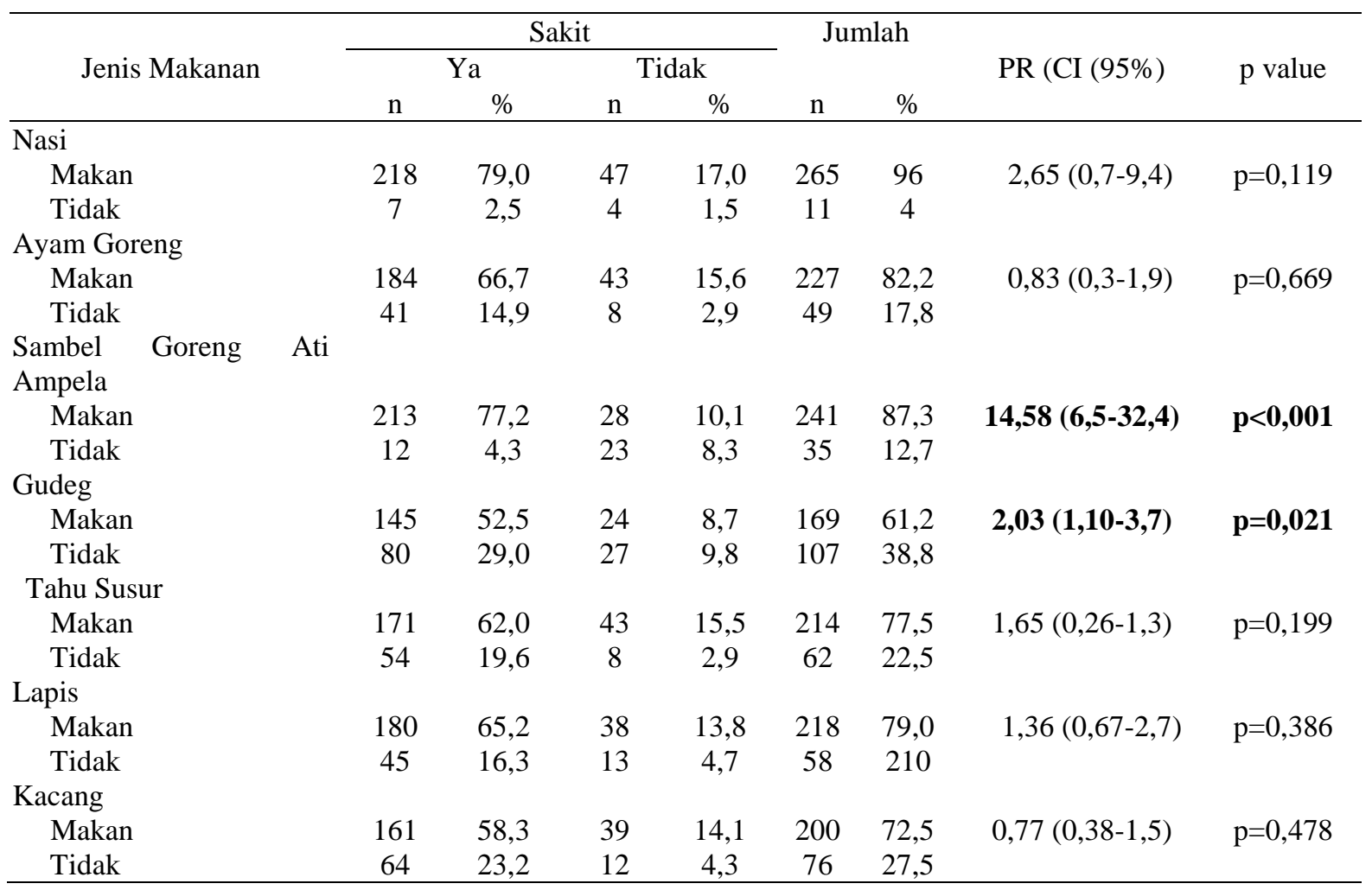

Tabel 2. Hasil Uji Multivariat Jenis Makanan terhadap KLB Keracunan Makanan

\begin{tabular}{lcrrrc}
\hline Jenis Makanan & \multicolumn{1}{c}{ Wald } & \multicolumn{1}{c}{$p$ value } & \multicolumn{1}{c}{$\mathrm{R}$} & CI 95\% \\
\hline Nasi & $-0,078$ & 0,009 & 0,923 & 0,925 & $0,192-4,450$ \\
Sambal Goreng Ati & 2,649 & 36,233 & $<\mathbf{0 , 0 0 1}$ & $\mathbf{1 4 , 1 4}$ & $\mathbf{5 , 9 7 0 - 3 3 , 5 1}$ \\
Gudeg & 0,523 & 1,899 & 0,168 & 1,680 & $0,802-3,547$ \\
Tahu Susur & $-0,987$ & 3,932 & 0,470 & 0,373 & $0,141-0,989$ \\
Konstanta & $-0,060$ & 0,005 & 0,944 & 0,942 & \\
\hline
\end{tabular}

\section{Hasil Laboratorium}

Berikut adalah hasil pemeriksaan bakterologi pada sampel makanan/minuman yang dikonsumsi pada acara Kartini's Day. Berdasarkan Tabel 3 dapat diketahui bahwa beberapa makanan yang telah mengalami kerusakan seperti ayam goreng, sambal goreng ati, tahu bakso, dan kacang. Hal tersebut ditandai dengan adanya mikroorganisme khamir dan kapang dalam makanan tersebut.

Tabel 3 juga menjelaskan bahwa penyebab keracunan makanan adalah adanya bakteri Enterobacter aerogenes yang terdapat pada ayam dan sambal goreng ati. Enterobacter adalah bakteri patogen yang dapat menyebabkan infeksi opurtunistik salah satunya infeksi saluran pencernaan.(Kassahun and Wongiel, 2019) 
Tabel 3. Hasil Pemeriksaan Bakterologi

\begin{tabular}{cll}
\hline No & Nama Makanan/Minuman & \multicolumn{1}{c}{ Mikroorganisme yang terkandung } \\
\hline 1 & Nasi Putih & Bacillus sp, Enterobacter aglomerans \\
2 & Ayam Goreng & $\begin{array}{l}\text { Khamir, Bacillus sp, Enterobacter aerogenes, Staphylococcus } \\
\text { saprophyticus }\end{array}$ \\
3 & Sambel Goreng Ati & Khamir, Bacillus sp, Enterobacter aerogenes \\
4 & Gudeg & Bacillus sp, Proeus mirabilis \\
5 & Tahu Bakso & Kapang (Monilia sp), Bacillus sp, Serratia liquifacien, \\
& & Staphylococcus saprophyticus \\
6 & Kacang & Kapang (Monilia sp), Alfa Streptococcus \\
7 & Air Mineral Kemasan & Bacillus sp, Serratia liquifaciens \\
\hline
\end{tabular}

\section{Penanggulangan yang Telah Dilakukan}

a. Memberikan pengobatan kepada penderita.

b. Melakukan pelacakan kasus sekaligus memberikan penyuluhan pada kepada masyarakat melalui perangkat desa dan kader kesehatan untuk pencegahan penularan lebih luas.

c. Pengambilan sampel makanan dan pengiriman ke Balai Laboratorium Kesehatan Kabupaten Wonosobo untuk mencari penyebab keracunan makanan.

d. Pemantauan perkembangan kasus dengan melakukan pengamatan dua kali masa inkubasi.

\section{KESIMPULAN}

Telah terjadi KLB Keracunan Makanan di Desa Parikesit Kecamatan Kejajar setelah warga mengkonsumsi makanan katering dalam acara Kartini's Day dengan jumlah kasus sebanyak 225 penderita, Attack Rate sebesar: 11,07\% dengan Case Fatality Rate: 0\%. Kasus mulai ada dari tanggal 24 Maret 2019 dan puncak kasus terjadi pada tanggal 25 Maret 2019 dan kasus terakhir terdapat pada tanggal 27 Maret 2019, sehingga pada tanggal 29 Maret 2019 KLB dinyatakan sudah berakhir. Bakteri penyebab keracunan makanan adalah Enterobacter aerognes yang terdapat pada makanan Ayam Goreng dan Sambal Goreng Ati.

\section{DAFTAR PUSTAKA}

Centers for Diseases Control and Preventions (2020) Foodborne Outbreaks, CDC Website. Available at: https://www.cdc.gov/foodsafety/outbreaks/index.html (Accessed: 25 June 2020).

Ditjen P2PL (2011) Buku Pedoman Penyelidikan dan Penanggulangan Kejadian Luar Biasa Penyakit Menular dan Keracunan Pangan (Pedoman Epidemiologi Penyakit). Revisi Tahun 2011. Jakarta.

Kassahun, M. and Wongiel, S. (2019) 'Food poisoning outbreak investigation in Dewachefa woreda, Oromia Zone, Amhara Region, Ethiopia, 2018', BMC Research Notes. BioMed Central Ltd. doi: 10.1186/s13104-019-4407-9.

Kemenkes RI (2004) Pedoman Penyelenggaraan Sistem Kewaspadaan Dini Kejadian Luar Biasa (KLB), Kemenkes RI. Peraturan Menteri Kesehatan.

Pertiwi, J. et al. (2019) 'SISTEM KEWASPADAAN DINI (SKD) KLB DBD DI KABUPATEN SRAGEN', JMIAK (Jurnal Manajemen Informasi dan Administrasi Kesehatan), 02(02), pp. 44-50. Available at: http://journal.univetbantara.ac.id/index.php/jmiak-rekammedis/article/view/456.

Rokhmayati, R. and Heryantoro, L. (2017) 'Penyelidikan Kejadian Luar Biasa (KLB) Keracunana Makanan di Kabupaten Gunung Kidul Daerah Istimewa Yogyakarta', 
Jurnal Formil Kesmas Respati, 02(02), pp. 17-28.

U.S. Food \& Drugs Administration (2020) Outbreaks of Foodborne Illness, FDA Website. Available at: https://www.fda.gov/food/recalls-outbreaks-emergencies/outbreaksfoodborne-illness\#investigations (Accessed: 25 June 2020). 